\title{
Links between Transformational Leadership and Organizational Performance in Colleges and Universities: Mediating Effects of Organizational Innovation
}

\author{
Yang Cheng \\ The Counseling Center \\ Nanchang Institute of Technology \\ Nanchang, china \\ yangcheng@nit.edu.cn
}

\begin{abstract}
Purposes: Empirical Study of transformational leadership, organizational innovation and organizational performance. Procedures: This paper putted forward relevant hypotheses, constructed models, and framed variables into a questionnaire. Methods: Used the analysis of multiple linear regressions and the effects analysis in MANOVA. Results: The Questionnaire has good reliability and validity indicators. the model is acceptable. Conclusions: Organizational innovation played a mediating role on the relationship between transformational leadership and organizational performance in colleges and universities.
\end{abstract}

Keywords-transformational leadership;organizational innovation; organizational performance

\section{INTRODUCTION}

In the field of organization and management research, leadership effectiveness has always been a concerned topic $^{[1]}$. China's higher education is experiencing the denotative development to connotative development, how to adapt to new situation improve organizational performance, organizational innovation is particularly important, as well as the guarantee for organizational development and performance improvement. In the process of innovation, leadership is the first resource of the organization. The combination of organizational innovation and leadership style, will be impact on driving force and the improvement of organizational performance $^{[2]}$. Researches have shown that, transformational leadership is more effective than other leadership styles. However, previous studies mainly in enterprise group as the investigation object, the research of organizational innovation in universities situations are relatively few. Research on transformational leadership, organizational innovation and organizational performance in colleges and universities, which will be conducive to understanding the interaction and promoting the development of higher education.

\section{CORE CONCEPT}

For over 30 years, leadership styles has shifted from tradition to a new theory of leadership-transformational leadership. Transformational leadership theory is put forward by Burns firstly in 1978, and Bass developed it on
"Leadership and Performance Beyond Expectation" in 1985. In colleges and universities, transformational leadership is means clerks change the values and beliefs by leader, and raise its demand levels ${ }^{[3]}$. The concept of innovation from Schumpter putted forward in 1912, means that innovation is to improve the efficiency of resource allocation of "new combination" activity. Organizational innovation in universities should take account of the innovation factors are: administrative service, infrastruction, resource utilization, education and teaching, innovation climate. On the discussion of the definition and measurement of organizational performance, has yet to obtain consistent conclusions ${ }^{[4]}$. Refer to the previous researches, this study introduced the balanced scorecard from four dimensions for organizational performance, which is finance, customer, internal business processes, development. So, organizational performance in universities including finance, staff satisfaction, teaching and scientific research, social satisfaction ${ }^{[5]}$.

\section{RESEARCH HYPOTHESIS}

\section{A. Transformational leadership and organizational performance in colleges and universities}

The leadership style have strong influence on organizational innovation in the literatures, it can create a positive and have incentive effect of organizational atmosphere, make fully implement responsibility of the employees in their jobs, and maximize organizational performance. A meta-analysis on past 75 studies with MLQ founded that: transformational leadership and leadership effectiveness are positive correlation in different background $^{[6]}$. Some scholars compared the predictive power of different leadership theory in China, who confirmed that transformational leadership had the strongest predictive power on leadership effectiveness than others $^{[7]}$. From the above, we hypothesized that:

H1: Transformational leadership had a positive impact on organizational performance in colleges and universities.

\section{B. Transformational leadership and organizational innovation in colleges and universities}

The role of leadership style on organizational innovation had been the scholars concerned. Effective 
leadership to provide higher quality, more efficient products and services, paying attention to organizational cohesion, personal development, job satisfaction, vision and goals, innovation mechanism and culture resources ${ }^{[8]}$. Leadership style of senior manager are increasingly becoming the important decisive factor of organizational creativity. Transformational leadership in many cases be verified to enhance the subordinate's creativity and motivation ${ }^{[9]}$. From the above, We hypothesized that:

$\mathrm{H} 2$ : Transformational leadership had a positive impact on organizational innovation in colleges and universities.

\section{Organizational innovation and organizational performance in colleges and universities}

Organizational innovation is not only make the organization has strong adaptability and vitality, but also to improve organizational performance, which has been supported by many scholars of empirical research. The managing and technological innovation of organization, its operating performance is higher than without ${ }^{[10]}$. Organizational innovation accelerate the improvement of the quality of the product development, improve the enterprise's market share, eventually the performance of the organization. From the above, we hypothesized that:

H3: Organizational innovation had a positive impact on organizational performance in colleges and universities.

\section{Transformational leadership, organizational innovation and organizational performance in colleges and universities}

Comprehensived the above literature review and research hypothesis, this article tried to take relationship for transformational leadership, organizational innovation, and organizational performance in colleges and universities. We hypothesized that:

$\mathrm{H} 4$ :Organizational innovation helped to transformational leadership's impact on organizational performance in colleges and universities.

\section{RESEARCH DESIGN}

From the perspective of management psychology, and by consulted the relevant literatures, the "Questionnaire on the University Management Practice" has been designed. Then with the analysis of multiple linear regressions and the effects analysis in MANOVA, the model was validated.

\section{A. Research Sample}

In view of the sample selection, this paper mainly considered the following factors: representativeness of sample survey, effective questionnaire returns-ratio. This study adopts the method of stratified sampling, different subjects scores averaged of the same unit as a sample data. Researchers contacted college senior executives surveyed firstly, after confirmation can be investigated, then mailed questionnaire investigation. 34 colleges and universities were chosed to investigate, included 2 "211 engineering universities", 21 universities, 11 college and higher vocational colleges. From the school size, the number of faculty in 4 colleges and universities under 500 ; the number of teaching staff members in 8 colleges and universities from 501 to 1000 ; the number of teaching staff members in 11 colleges and universities from 1001 to 2000 ; the number of teaching staff members in 11 colleges and universities in more than 2000. Each unit requirements by investigators had three years work experience, 2 or 3 copies of the questionnaire for school leaders, 4 copies of the questionnaire for the middle-level manager, 1 or 2 copies of the questionnaire for grassroots cadres or teachers. The total of 292 questionnaires were issued, and the valid response rate was $100 \%$.

\section{B. Measurement variable}

- Transformational leadership measurement mainly refer to transformational leadership scale by $\mathrm{Li}$ Chaoping and Shikan, involving virtue, charisma, vision incentive, personalized care. The measurement had nine items ${ }^{[11]}$.

- Organizational innovation took account of the innovational factors are: administrative service, infrastruction, resource utilization, education and teaching, innovative climate ${ }^{[12]}$. The measurement had twenty-five items ${ }^{[13]}$.

- Organizational performance included finance, staff satisfaction, teaching and scientific research, social satisfaction. The measurement had fourteen items.

- Used the likert five scoring method from "completely not " to "completely yes" to measure all the variables.

\section{Reliability and validity of the questionnaire}

Based on many internal or

external literatures, the author presented the interview outline, and interviewed with leaders of four universities. Through literature review and interviewed to leaders, the preliminary questionnaire compiled, then the formal questionnaire was issued. To improve the reliability and validity, putted the sample by investigators of each college the same topic data average, we analysis the original data are obtained.

With Cronbach's $\alpha$ coefficient to check the reliability of the variable. Various factors and variables of Cronbach's $\alpha$ value was above 0.89 , showed that the questionnaire had good reliability(Table 1$)$.

TABLE I. THE DESCRIPTIVE STATISTICS OF THE VARIABLES AND THE RELIABILITY ANALYSIS

\begin{tabular}{|c|c|c|c|c|}
\hline $\begin{array}{c}\text { Factors or } \\
\text { variables }\end{array}$ & Items & Average & $\begin{array}{c}\text { Standard } \\
\text { deviation }\end{array}$ & $\begin{array}{c}\text { Cronbach's } \\
\boldsymbol{\alpha}\end{array}$ \\
\hline $\begin{array}{c}\text { Transforming } \\
\text { Leadership }\end{array}$ & 9 & 4.366 & .421 & 0.970 \\
\hline $\begin{array}{c}\text { Organizational } \\
\text { Innovation }\end{array}$ & 25 & 4.096 & .365 & 0.979 \\
\hline $\begin{array}{c}\text { Administrative } \\
\text { Service }\end{array}$ & 5 & 4.168 & .425 & 0.951 \\
\hline $\begin{array}{c}\text { Infrastruction } \\
\text { Resource } \\
\text { Utilization }\end{array}$ & 5 & 4.111 & .415 & 0.921 \\
\hline $\begin{array}{c}\text { Education and } \\
\text { Teaching }\end{array}$ & 5 & 4.104 & .390 & 0.916 \\
\hline $\begin{array}{c}\text { Innovative } \\
\text { Climate }\end{array}$ & 5 & 4.006 & .405 & 0.953 \\
\hline $\begin{array}{c}\text { Organizational } \\
\text { Performance }\end{array}$ & 14 & 3.845 & .467 & 0.955 \\
\hline $\begin{array}{c}\text { Finance } \\
\text { Staff Satisfaction }\end{array}$ & 3 & 3.650 & .592 & 0.893 \\
\hline $\begin{array}{c}\text { Teaching and } \\
\text { Research }\end{array}$ & 3 & 3.878 & .533 & 0.916 \\
\hline $\begin{array}{c}\text { Social } \\
\text { Satisfaction }\end{array}$ & 4 & 4.083 & .446 & 0.917 \\
\hline
\end{tabular}


Content validity was used as validity index. The questionnaire of this research reference for the domestic and foreign relevant questionnaire, through the preliminary test and consulting relevant experts, the questionnaire was revised, which ensures the good content validity.

\section{Data processing and analysis}

- This information was used SPSS13.0 statistical soft ware package to record and analyse.

- During importing data into database, the validity of data fields checked assure of the valid of original data.

- This article also took such statistical measures as, MANOVA, correlative analysis, regression analysis, and so on.

\section{RESEARCH RESULTS}

\section{A. The correlation analysis between the variables}

Through the related analysis found:

1) Transformational leadership and all dimensions of organizational performance had significant correlation. The more transformational leadership, the greater the organizational performance, the better in finance, staff satisfaction, teaching and scientific research, social satisfaction performance .

2) Transformational leadership and all dimensions of organizational innovation had significant correlation. The more transformational leadership, the greater the organizational innovation, the better in administrative service, infrastruction, resource utilization, education and teaching, innovative climate.

3) All dimensions organizational innovation and all dimensions of organizational performance had significant correlation.

4) School size had not related with transformational leadership, organizational innovation, organizational performance.

\section{B. Hypothesis Testing}

1) The influence of transformational leadership on the organizational performance. Transformational leadership as the independent variable, organizational performance and its four elements as the dependent variable, by stepwise regression analysis. The results were shown in Table 2. Therefore, research hypothesis $\mathrm{H} 1$ gained their support.

2) The influence of transformational leadership on the organizational innovation. Transformational leadership as the independent variable, organizational innovation and its five elements as the dependent variable, by stepwise regression analysis. The results were shown in Table 3. Therefore, research hypothesis $\mathrm{H} 2$ gained their support.
TABLE II. THE REGRESSION ANALYSIS RESULTS BETWEEN TRANSFORMATIONAL LEADERSHIP AND ORGANIZATIONAL PERFORMANCE

\begin{tabular}{|c|c|c|c|c|c|}
\hline \multirow[b]{2}{*}{$\begin{array}{c}\text { Independent } \\
\text { Variable }\end{array}$} & \multicolumn{5}{|c|}{ Dependent Variable } \\
\hline & $\begin{array}{c}\text { Organizational } \\
\text { Performance }\end{array}$ & Finance & $\begin{array}{c}\text { Staff } \\
\text { Satisfaction }\end{array}$ & $\begin{array}{c}\text { Teaching } \\
\text { and } \\
\text { Research }\end{array}$ & $\begin{array}{l}\text { Social } \\
\text { Satisfa } \\
\text {-ction }\end{array}$ \\
\hline School Size & 0.112 & 0.007 & 0.000 & 0.171 & 0.249 \\
\hline $\begin{array}{l}\text { Transforming } \\
\text { Leadership }\end{array}$ & $0.659^{* * *}$ & $0.588^{* * *}$ & $0.700^{* * *}$ & $0.596^{* * *}$ & $\begin{array}{l}0.475 \\
* *\end{array}$ \\
\hline Adjusted $\mathrm{R}^{2}$ & 0.409 & 0.303 & 0.456 & 0.341 & 0.238 \\
\hline$\triangle \mathrm{F}$ & 24.236 & 16.362 & 29.695 & 17.810 & 9.775 \\
\hline
\end{tabular}

PS: *express $\mathrm{p}<.05, * *$ express $\mathrm{p}<.01, * * *$ express $\mathrm{p}<.001$ (two-sided test $)$, the same below.

TABLE III. THE REGRESSION ANALYSIS RESULTS BETWEEN TRANSFORMATIONAL LEADERSHIP AND ORGANIZATIONAL INNOVATION

\begin{tabular}{|c|l|l|l|l|l|l|}
\hline \multirow{2}{*}{$\begin{array}{c}\text { Independ- } \\
\text { ent } \\
\text { Variable }\end{array}$} & $\begin{array}{c}\text { Organiza } \\
- \text { tional } \\
\text { Innov- } \\
\text { ation }\end{array}$ & $\begin{array}{c}\text { Adminis- } \\
\text { trative } \\
\text { Service }\end{array}$ & $\begin{array}{c}\text { Infras- } \\
\text { truction }\end{array}$ & $\begin{array}{c}\text { Resource } \\
\text { Utiliza- } \\
\text { tion }\end{array}$ & $\begin{array}{c}\text { Education } \\
\text { and } \\
\text { Teaching }\end{array}$ & $\begin{array}{c}\text { Innova- } \\
\text { tive } \\
\text { Climate }\end{array}$ \\
\hline $\begin{array}{c}\text { School } \\
\text { Size }\end{array}$ & 0.131 & 0.045 & 0.179 & 0.177 & 0.174 & 0.025 \\
\hline $\begin{array}{c}\text { Transform- } \\
\text { ing } \\
\text { Leadership }\end{array}$ & $0.797^{* * *}$ & $0.883^{* * *}$ & $0.598^{* * *}$ & $0.701^{* * *}$ & $0.690^{* * *}$ & $0.764^{* * *}$ \\
\hline $\begin{array}{c}\text { Adjusted } \\
\mathrm{R}^{2}\end{array}$ & 0.626 & 0.767 & 0.346 & 0.487 & 0.471 & 0.557 \\
\hline$\triangle \mathrm{F}$ & 55.957 & 110.508 & 18.029 & 31.591 & 29.685 & 43.447 \\
\hline
\end{tabular}

3) The influence of organizational innovation on the organizational performance. Organizational innovation as the independent variable, organizational performance and its four elements as the dependent variable, by stepwise regression analysis. The results were shown in Table 4. Therefore, research hypothesis H3 gained their support.

TABLE IV. THE REGRESSION ANALYSIS RESULTS BETWEEN ORGANIZATIONAL INNOVATION AND ORGANIZATIONAL PERFORMANCE

\begin{tabular}{|c|c|c|c|c|c|}
\hline \multirow[b]{2}{*}{$\begin{array}{c}\text { Independent } \\
\text { Variable }\end{array}$} & \multicolumn{5}{|c|}{ Dependent Variable } \\
\hline & $\begin{array}{c}\text { Organiza- } \\
\text { tional } \\
\text { Innovation }\end{array}$ & Finance & $\begin{array}{c}\text { Staff } \\
\text { Satisfacti } \\
\text { on }\end{array}$ & $\begin{array}{c}\text { Teaching } \\
\text { and } \\
\text { Research }\end{array}$ & $\begin{array}{c}\text { Social } \\
\text { Satisfaction } \\
\end{array}$ \\
\hline School Size & 0.003 & -0.089 & -0.102 & 0.068 & 0.160 \\
\hline $\begin{array}{c}\text { Organizational } \\
\text { Performance }\end{array}$ & $0.829^{* * *}$ & $0.728^{* * *}$ & 0.767 & 0.789 & 0.680 \\
\hline Adjusted $\mathrm{R}^{2}$ & 0.668 & 0.492 & 0.552 & 0.616 & 0.482 \\
\hline$\triangle \mathrm{F}$ & 67.380 & 34.007 & 42.704 & 52.798 & 29.036 \\
\hline
\end{tabular}

4) The mediation effect of organizational innovation. More than only considered the direct effect between the variable, to established three regression model by used stepwise regression analysis method. Taked advantage of stepwise regression, we found mediating effects of organizational innovation between transformational leadership and organizational performance. The results were shown in Table 5. Therefore, research hypothesis $\mathrm{H} 4$ gained their support. 
TABLE V. THE MEDIATION EFFECT OF ORGANIZATIONAL INNOVATION

\begin{tabular}{|c|l|l|l|}
\hline \multirow{2}{*}{ Independent Variable } & \multicolumn{3}{|c|}{$\begin{array}{c}\text { Dependent Variable } \\
\text { (Organizational Performance) }\end{array}$} \\
\cline { 2 - 4 } & Model 1 & \multicolumn{1}{|c|}{ Model 2 } & Model 3 \\
\hline Control Variable & & & \\
\hline School Size & 0.101 & 0.112 & 0.003 \\
\hline Transforming Leadership & & $0.659^{* * *}$ & -0.004 \\
\hline Organizational Innovation & & & $0.833^{* * *}$ \\
\hline Adjusted $\mathrm{R}^{2}$ & 0.010 & 0.445 & 0.688 \\
\hline$\triangle \mathrm{F}$ & 0.332 & 24.236 & 24.434 \\
\hline
\end{tabular}

\section{CONCLUSION}

\section{A. Transformational leadership in colleges and} universities was beneficial to the improvement of the organizational performance and related performance dimension.

Through regression analysis we find ,when transformational leadership increase 1 percent point, the ratio of organization performance increase by 0.727 . Especially involved leader authority within the scope of the performance, such as financial performance, staff satisfaction, teaching and scientific research. Social satisfaction in small increments. Domestic and international relevant researches had similar results.

Maybe the idea and behavior of transformational leadership can inspire the staff, who work on teaching, scientific research, and improve the cohesion of organization. About staff satisfaction: a transformational leader develop others to help them grow in their jobs. Placed critical importance on performance management and encourages personal development. About teaching and research: a transformational leader is being open-mind, putting the right people in the right seats, normalizing teaching management, strengthening research, attracting talent. About finance: enabling staff incomes to rise. About social satisfaction: a transformational leader focus on innovation, students have high recognition from enterprise and society. Analysis data shows that transformational leadership can explain about $58 \%$ of each performance dimensions.

\section{B. Transformational leadership in colleges and} universities was beneficial to the improvement of the organizational innovation and related performance dimension.

Transformational leadership in organizational innovation accounts for $79.7 \%$, in administrative service accounts for $88.3 \%$, in innovative climate accounts for $76.4 \%$, in resource utilization accounts for $70.1 \%$, in education and teaching accounts for $69 \%$, in infrastruction accounts for $59.8 \%$. About administrative service: a transformational leader leading comrades play a leading role, and the whole staff take part in, to built prospective, effective innovative directions. About infrastruction: it lies in utilize the modern method, develops the culture the industry, unfolds its cultural vitality and promotes. About resource utilization: a transformational leader develops each kind of human resources, to built up in order to develop students' comprehensive quality and creative ability. About education and teaching: a transformational leader take part in the discipline and teaching construction actively, encourage students to enter the competition. About innovative climate: a transformational leader introduce new ideas and provides employees competitive compensation and helps employees to achieve individual objectives.

\section{Organizational innovation played a mediating role on the relationship between transformational leadership and organizational performance.}

Organizational innovation had not significant effects on organizational performance. In further regression analysis, we found there are a significant interaction between transformational leadership and organizational innovation on organizational performance. Organizational innovation totally explain $83.3 \%$ of the organizational performance, but transformational leadership not. This conclusion may be related to the effectiveness of transformational leadership was influenced by the situational and follower's variables in the view of contingency theories. Secondly, education and teaching totally explain $49.5 \%$ of the organizational performance, is the most significant intermediary variable.

\section{REFERENCES}

[1] Hiller, N. J., DeChurch, L. A., Murase, T., \& Doty, D. Searching for outcomes of leadership: A 25-year review[J]. Journal of Management 2011,37, 1137-1177.

[2] [12]WANG Yai-fei,ZHU Yu. Moderating Effect of Organizational Learning on the Relationship between Organizational Innovation and Performance[J]. Chinese Journal of Management, 2009, 9 (9):1257.

[3] WU Zhi-guo. Research on relationship model of transformational leadership,organizational climate for innovativeness and innovative performance[D]. Shanghai Jiao Tong University,2008.

[4] Cameron K.Measuring organizational Effeetiveness in Institution of Higher Education[J]. Administrative Seience Quarteriy, 1978 , 23:604-629.

[5] XING Zhou-ling, LI Wen-zhi. Study of Organizationa Performance Model of Chinese Universities[J]. Higher Education Exploration,2010(2):10-17.

[6] Lowe, K.B., K.GKroeck..N..Sivasubramaniam..Effeetiveness of Correlates of Transformational and Transactional Leadership: A MetaAnalytic Review of the MLQ Literature[J]. Leadership Quartery,1996,7:385-425.

[7] LI Chao-ping, MENG Hui, SHI Kan. The Effects of Transformational Leadership on Organizational Citizenship Behavior[J]. Psychological Science 2006,29(1):175-177

[8] Ekvall , G. , Ryhammar, L. The Creative Climate: it Determinant sand Effects at a Swedish University[J]. Creativity Research Journal, 1999, 12:303-310.

[9] Tichy, N.M., Ulrieh, D.O.The Leadership Challenges a Call for the Transformational Leader[J].Sloan Management Review, 1984 , 26:59-68

[10] Damanpour, F., Evan, W.M. Organizational Innovation and Performance: The Problem of Organizational Lag.Administrative Science Quarterly, 1984, 29:392-409.

[11] [13] LI Chao-ping, SHI Kan. The Structure and Measurement of Transformational Leadership in China[J]. Acta Psychologica Sinica, 2005 (6) : 803-811 